\title{
PENGARUH PENGUNGKAPAN TANGGUNG JAWAB SOSIAL PERUSAHAAN TERHADAP NILAI PERUSAHAAN DENGAN MEDIA ATTENTION SEBAGAI VARIABEL MEDIASI
}

(Studi Kasus Pada Perusahaan Manufaktur Yang Terdaftar Di Bursa Efek Indonesia Tahun 2016)

FIDDYANA LASIMPALA, MARIA NATALIA*

Program Studi Akuntansi Fakultas Ekonomi, Universitas Kristen Maranatha *Email: maria2312natalia@gmail.com

\begin{abstract}
The objective of this research is to determine the impact of Corporate Social Responsibility Disclosure to firm value with media attention as mediating variable. In this research media attention is proxied with a website, while firm value is measured using the Tobin's q ratio. The population in this research are manufacturing companies that listed on the Indonesia Stock Exchange in 2016. This research refers to Li et al. (2016) \& Putra et al. (2017) research which shows that the performance of Corporate Social Responsibility is positively related to firm value. The difference between this research and previous research is the use of 144 manufacturing companies listed on the Indonesian Stock Exchange in 2016 as a research sample. Corporate Social Responsibility Disclosure measured using performance indicators from the Global Reporting Initiative (GRI) 4.1.Sampling was conducted using a purposive sampling method with criteria the companies that publish information related to Corporate Social Responsibility in the year of 2016 at annual report and at the company's official website. The sample of research that meets the criteria are 87 samples. Type of data used in this research is secondary data that obtained through official www.idx.co.ic. The data were analyzed by using path analysis with the SPSS 20 application. The results showed that the Corporate Social Responsibility Disclosure had an effect on the firm value. Meanwhile, media attention is not able to mediate the influence of Corporate Social Responsibility Disclosure on firm value.
\end{abstract}

Keywords : Corporate Social Responsibility; media attention; firm value; GRI

\section{PENDAHULUAN}

Fenomena lautan busa yang menyelimuti aliran air di Banjir Kanal Timur (BKT) Marunda, Jakarta Utara, termasuk permasalahan yang merusak lingkungan. Busa ini berasal dari limbah rumah tangga, khususnya detergen. Pemerintah menghimbau agar dilakukan review atas penggunaan detergen-detergen karena

* Corresponding author's e-mail: maria2312natalia@gmail.com

http://openjournal.unpam.ac.id/index.php/JIA 
Jurnal Ilmiah Akuntansi Universitas Pamulang - Vol. 8, No. 1, Januari 2020 - Lasimpala \& Natalia

penggunaannya yang makin bertambah sehingga ketika dikumpulkan akan menjadi volume detergen yang sangat besar (Anies Baswedan, 2018). Munculnya busa sebagai bentuk limbah detergen disebabkan oleh banyaknya masyarakat yang berbisnis menggunakan detergen, misalnya bisnis cuci kendaraan dan laundry. Detergen yang sering digunakan adalah detergen yang keras. Detergen keras adalah detergen yang buihnya banyak karena kandungan MBAS (Metilen Blue Active Surfactan), hal tersebut kurang ramah bagi lingkungan walaupun harganya lebih murah. Saat ini belum terdapat detergen yang ramah lingkungan yang kandungan MBAS-nya rendah di Indonesia.

Menurut Dirjen Mineral dan Batubara Kementerian ESDM Thamrin Sihite, sebagian besar perusahaan yang merusak lingkungan belum memandang penting program Corporate Social Responsibility terhadap masyarakat atau lingkungan sekitar. Dampak negatif yang ditimbulkan dari usaha masing-masing perusahaan harus bisa diminimalisir oleh perusahaan itu sendiri misalkan dengan melakukan Corporate Social Responsibility melalui kegiatan lingkungan. Pelaksanaan program pertanggungjawaban sosial perusahaan merupakan investasi yang penting sebagai sarana untuk meningkatkan Nilai Perusahaan. Di Indonesia, kewajiban perusahaan untuk melakukan Corporate Social Responsibility tercantum dalam Undang-Undang Nomor 40 Tahun 2007 tentang Perseroan Terbatas (PT) yang telah disahkan pada tanggal 20 Juli 2007 (Putra, Kristiani \& Yudowati, 2017). "'Undang-Undang No. 40 Tahun 2007 tentang Perseroan Terbatas Pasal 74 ayat (1) menyatakan perseroan yang menjalankan kegiatan usahanya di bidang dan atau berkaitan dengan sumber daya alam wajib melaksanakan tanggung jawab sosial dan lingkungan. Ayat (2) pasal ini manyatakan kewajiban tersebut diperhitungkan sebagai biaya perseroan yang pelaksanaannya dilakukan dengan memperhatikan kepatutan dan kewajaran. Selanjutnya ayat (3) menyebutkan perseroan yang tidak melaksanakan kewajiban sebagaimana yang dimaksud ayat (1) dikenai sanksi sesuai dengan peraturan perundang-undangan yang terkait. Kemudian ayat (4) menyatakan ketentuan lebih lanjut mengenai tanggung jawab sosial dan lingkungan diatur dengan Peraturan Pemerintah', (Marnelly, 2012).

Corporate Social Responsibility atau tanggung jawab sosial perusahaan adalah suatu gagasan yang membuat perusahaan juga bertanggungjawab terhadap masalah sosial dan lingkungan di sekitar perusahaan, bukan hanya berfokus dalam hal keuangan sehingga perusahaan dapat tumbuh secara berkelanjutan (Putra, Kristiani \& Yudowati, 2017). Tanggung jawab sosial perusahaan atau Corporate Social Responsibility adalah semua bentuk upaya yang dilaksanakan perusahaan agar tujuan pembangunan yang berkelanjutan yang berdasarkan pada keseimbangan pilar ekonomi, sosial serta lingkungan dapat tercapai, dengan memaksimalkan dampak positif serta meminimumkan dampak negatif di setiap pilar (Sucada dalam Ananda, 2017). Sejumlah riset menunjukkan Corporate Social Responsibility merupakan aset tidak berwujud yang dapat menjadi value creator dan sangat strategis bagi perusahaan dalam jangka panjang (Lamo, 2015). Dalam pengambilan keputusan investasi, banyak investor yang memperhatikan Corporate Social Responsibility yang diungkapkan oleh perusahaan (Rosiana, Juliarsa \& Sari, 2013). Investor bereaksi positif terhadap publikasi laporan 
Jurnal Ilmiah Akuntansi Universitas Pamulang - Vol. 8, No. 1, Januari 2020 - Lasimpala \& Natalia

keuangan dari perusahaan-perusahaan yang mengungkapkan lebih banyak informasi Corporate Social Responsibility dan membukukan peningkatan laba. Sebaliknya, investor bereaksi negatif terhadap publikasi laporan keuangan dari emiten yang mengungkapkan sedikit informasi Corporate Social Responsibility dan membukukan penurunan laba (Lamo, 2015).

Sartono dalam Dewi \& Wirajaya (2013) menyatakan bahwa salah satu tujuan perusahaan yang berkaitan dengan kemakmuran pemegang saham adalah memaksimalkan Nilai Perusahaan. Saat ini persaingan dalam industri manufaktur membuat setiap perusahaan manufaktur berusaha untuk terus meningkatkan kinerja agar tujuan tersebut dapat terealisasi. Putra et al. (2017) menyatakan bahwa salah satu investasi yang penting bagi perusahaan dalam meningkatkan Nilai Perusahaan adalah pelaksanaan program Corporate Social Responsibility atau pertanggungjawaban sosial perusahaan. Corporate Social Responsibility dan aktivitas Corporate Social Responsibility diapresiasi dan dilihat oleh investor sebagai pedoman dalam menilai potensi keberlanjutan dari suatu perusahaan (Rosiana, Juliarsa \& Sari, 2013). Salah satu bagian sistematis yang harus dilaksanakan perusahaan tanpa syarat apapun adalah bertanggungjawab dalam mengelola dampak negatif perusahaan atau melaksanakan suatu kegiatan pengolahan lingkungan akibat dampak negatif operasional perusahaan, karena tanggung jawab sosial akan dipandang sebagai suatu sikap yang penting dalam meningkatkan laba yang akan memperkuat Nilai Perusahaan (Kartini, 2009).

Saat ini banyak perusahaan yang mungkin memprioritaskan Corporate Social Responsibility tetapi gagal untuk berkomunikasi dengan para pemangku kepentingan dan hal tersebut akan mempengaruhi bisnis perusahaan (Amaladoss \& Manohar, 2013). Oleh karena itu, penting bagi perusahaan untuk menemukan cara komunikasi yang efektif untuk menyebarkan informasi tentang kegiatan Corporate Social Responsibility yang sudah dilakukan, salah satunya melalui media. Umumnya, perhatian media tidak hanya mengurangi asimetri informasi bagi para pemangku kepentingan yang tidak memiliki interaksi langsung dengan perusahaan, tetapi juga mampu mempengaruhi opini publik. Berdasarkan hal tersebut, perhatian media terhadap kinerja Corporate Social Responsibility memungkinkan para pemangku kepentingan untuk membuat lebih banyak keputusan yang masuk akal ketika berhadapan dengan perusahaan, sehingga hal tersebut dapat mempengaruhi Nilai Perusahaan ( $\mathrm{Li}$ et al.,2016). Nilai Perusahaan adalah harga jual perusahaan yang layak menurut investor sehingga investor mau membayarnya apabila suatu perusahaan akan dijual. Indikator Nilai Perusahaan bagi perusahaan yang menjual sahamnya kepada masyarakat (go public) adalah harga saham yang diperjualbelikan di Bursa Efek (Sattar, 2017).

Ketidaktaatan industri manufaktur berkaitan dengan aspek pencemaran air, pengelolaan limbah dan aspek pencemaran udara. Perusahaan manufaktur dianggap memiliki kontribusi yang cukup besar dalam masalah-masalah lingkungan tersebut karena perusahaan manufaktur merupakan perusahaan yang sering berinteraksi dengan masyarakat sekitar. Ditinjau dari proses produksinya, industri manufaktur merupakan industri yang produknya banyak dibutuhkan masyarakat sehingga mau tidak mau perusahaan manufaktur akan menghasilkan

* Corresponding author's e-mail: maria2312natalia@gmail.com

http://openjournal.unpam.ac.id/index.php/JIA 
Jurnal Ilmiah Akuntansi Universitas Pamulang - Vol. 8, No. 1, Januari 2020 - Lasimpala \& Natalia

limbah produksi (Permana, 2012). Di sisi lain perusahaan manufaktur merupakan perusahaan yang berskala besar apabila dibandingkan dengan perusahaan lain. Produk manufaktur tetap dibutuhkan, sehingga kecil kemungkinan bagi sektor ini untuk mengalami kerugian. Oleh sebab itu, saham perusahaan manufaktur dianggap tahan terhadap krisis ekonomi (Sari \& Haryanto, 2013). Di Indonesia sedang beredar isu bahwa OJK sedang mempersiapkan regulasi yang mewajibkan emiten untuk melaporkan pilar ekonomi, sosial dan lingkungannya. Hal tersebut mengindikasikan bahwa GRI Standards akan menjadi acuan utama bagi sekitar 500 lebih perusahaan yang terdaftar di BEI. Kontribusi dalam penelitian ini terletak pada variabal media attention sebagai variabel mediasi. Penggunaan variabel media attention didasari pada alasan bahwa variabel tersebut belum banyak diteliti oleh peneliti di Indonesia. Berdasarkan permasalahan dan teori penelitian sebelumnya maka judul yang diangkat oleh peneliti adalah "Pengaruh Corporate Social Responsibility Disclosure terhadap Nilai Perusahaan dengan Media Attention sebagai Variabel Mediasi (studi kasus pada perusahaan manufaktur yang terdaftar di BEI periode 2016).

\section{LANDASAN TEORI}

\section{Corporate Social Responsibility}

Menurut Said (2015) Corporate Social Responsibility pertama kali muncul pada tahun 1953, melalui penerbitan buku 'Social Responsibilities of Businessman' karya Howard Bowen yang dikenal dengan 'Bapak CSR'. Corporate Social Responsibility semakin dikenal pada tahun 1960-an ketika persoalan kemiskinan dan keterbelakangan makin menyita perhatian dari berbagai macam kelompok. The World Commission on Environment and Development (WCED) dalam Brundtland Report, pada tahun 1987 mengembangkan tiga komponen penting sustainable development, yakni economic growth, environmental protection dan social equity. KTT Bumi di Rio De Janeiro pada tahun 1992, menegaskan konsep pembangunan berkelanjutan harus dilakukan semua pihak termasuk perusahaan dengan berlandaskan pada perlindungan lingkungan hidup serta pembangunan ekonomi dan sosial. Tahun 1998, konsep Corporate Social Responsibility semakin popular didorong oleh kehadiran buku Cannibols With Forks : The Triple Bottom Line in 21't Century Nusiness (1998) karya John Elkington.

\section{Media Attention}

Amaladoss \& Manohar (2013) menjelaskan bahwa saat ini banyak perusahaan yang mungkin memprioritaskan Corporate Social Responsibility tetapi gagal berkomunikasi secara baik dengan para pemangku kepentingan dan hal tersebut akan mempengaruhi bisnis perusahaan. Penting bagi perusahaan untuk menemukan cara komunikasi yang efektif untuk menyebarkan informasi tentang kegiatan Corporate Social Responsibility mereka. Saluran komunikasi yang saat ini cukup terkenal adalah melalui media.(Grafstro \& Windell, 2011). Perhatian media seputar Corporate Social Responsibility menawarkan informasi

* Corresponding author's e-mail: maria2312natalia@gmail.com

http://openjournal.unpam.ac.id/index.php/JIA 
Jurnal Ilmiah Akuntansi Universitas Pamulang - Vol. 8, No. 1, Januari 2020 - Lasimpala \& Natalia

ke pasar modal dan meningkatkan pengawasan eksternal terhadap perilaku perusahaan. Perhatian media juga membantu membentuk citra perusahaan dan memberi pengaruh besar pada banyak aspek kinerjanya, termasuk manajemen, harga saham, dan keuangan perusahaan (Craven dan Marston, 1997). Ketika perusahaan menarik perhatian media karena berperilaku secara bertanggung jawab, mereka dianggap sebagai "warga negara yang baik" dan hal tersebut berpengaruh bagi citra perusahaan (Branco and Rodrigues 2008).

\section{Nilai Perusahaan}

Menurut Margaretha (2005) Nilai Perusahaan yang sudah go public tercermin dalam harga pasar saham perusahaan, sedangkan Nilai Perusahaan yang belum go public artinya nilainya terealisasi apabila perusahaan akan dijual (total aktiva dan prospek perusahaan, lingkungan, risiko usaha, , dan lain-lain). Menurut Mardiyanto (2009) nilai sekarang dari serangkaian arus kas masuk yang akan dihasilkan perusahaan pada masa mendatang disebut sebagai Nilai Perusahaan. Sejauh mana keberhargaan suatu perusahaan dalam satuan mata uang atau nilai sekarang dari seluruh aliran kas bersih yang dapat dihasilkan perusahaan dari saat tertentu hingga berakhirnya operasi perusahaan, disebut sebagai Nilai Perusahaan atau value of firm Budihardjo (2011). Nilai Perusahaan adalah harga yang bersedia dikeluarkan oleh investor apabila perusahaan tersebut dijual. Memaksimumkan kekayaan pemegang saham adalah tujuan normatif perusahaan (Sudana, 2009).

\section{METODOLOGI PENELITIAN}

\section{Jenis Penelitian}

Tujuan dari penelitian ini adalah untuk menguji apakah terdapat pengaruh Corporate Social Responsibility dan profitabilitas terhadap Nilai Perusahaan. Berdasarkan tujuan penelitian tersebut, maka jenis penelitian yang digunakan adalah causal explanatory. Menurut Alfianika (2016), causal explanatory merupakan penelitian dengan analisis data yang sampai pada langkah menentukan hubungan satu variabel dengan variabel lainnya. Causal Explanatory juga bisa disebut sebagai metode penelitian yang digunakan untuk memberikan penjelasan terkait kedudukan dari variabel yang diteliti dan pengaruh antara variabel yang satu dengan variabel lain. Hasil penelitian ini, menjelaskan hubungan kasual antara variabel yang satu dengan yang variabel yang lain melalui pengujian hipotesis (Sugiyono, 2014).

\section{Populasi dan Sampel}

Populasi dari penelitian ini adalah perusahaan yang tercatat di Bursa Efek Indonesia periode 2016. Teknik pengambilan sampel dalam penelitian ini adalah non-probability sampling dengan metode purposive sampling yang bertujuan untuk memperoleh kriteria yang telah ditentukan oleh peneliti. 
Jurnal Ilmiah Akuntansi Universitas Pamulang - Vol. 8, No. 1, Januari 2020 - Lasimpala \& Natalia

\section{Teknik Pengumpulan Data}

Teknik pengumpulan data dalam penelitian ini menggunakan data sekunder berupa Annual Report perusahaan manufaktur yang terdaftar di Bursa Efek Indonesia periode 2016 yang diperoleh melalui www.idx.co.id dan informasi terkait Corporate Social Responsibility yang diperoleh melalui website masingmasing perusahaan.

\section{HASIL PENELITIAN DAN PEMBAHASAN}

Uji Asumsi Klasik

Hasil Uji Normalitas

Tabel 1 Hasil Uji Normalitas

One-Sample Kolmogorov-Smirnov Test

\begin{tabular}{|c|c|}
\hline & $\begin{array}{l}\text { Unstandardized } \\
\text { Residual }\end{array}$ \\
\hline $\begin{array}{ll}\mathrm{N} & \\
\text { Normal } & \text { Mean } \\
\text { Parameters } & \text { Std. Deviation } \\
\text { Most Extreme } & \text { Absolute } \\
\text { Differences } & \text { Positive } \\
\text { Kolmogorov-Smirnov Z } \\
\text { Asymp. Sig. (2-tailed) }\end{array}$ & $\begin{array}{l}87 \\
0 \mathrm{E}-7 \\
2.37672333 \\
.188 \\
.188 \\
-.105 \\
1.750 \\
.439\end{array}$ \\
\hline
\end{tabular}

a. Test distribution is Normal.

b. Calculated from data.

Berdasarkan hasil uji normalitas yang terdapat dalam table 1 diperoleh nilai Asymp. Sig. (2-tailed)sebesar 0,439, yang berarti bahwa data yang diukur telah memiliki normalitas yang baik atau telah berdistribusi normal karena telah memiliki nilai yang lebih besar dari $5 \%$.

\section{Hasil Uji Multikolinearitas}

Tabel 2 Hasil Uji Multikolinearitas

\begin{tabular}{|c|c|c|c|c|c|c|c|}
\hline \multirow[t]{2}{*}{ Model } & \multicolumn{2}{|c|}{$\begin{array}{l}\text { Unstandardized } \\
\text { Coefficients }\end{array}$} & \multirow{2}{*}{$\begin{array}{l}\text { Standardized } \\
\text { Coefficients } \\
\text { Beta }\end{array}$} & \multirow[t]{2}{*}{$\mathrm{t}$} & \multirow[t]{2}{*}{ Sig. } & \multicolumn{2}{|c|}{$\begin{array}{l}\text { Collinearity } \\
\text { Statistics }\end{array}$} \\
\hline & $\mathrm{B}$ & Std. Error & & & & $\begin{array}{l}\text { Toleran } \\
\text { ce }\end{array}$ & VIF \\
\hline 1 (Constant) & 2.606 & 5.202 & & .501 & .618 & & \\
\hline Size & -.234 & .188 & -.134 & -1.248 & .216 & .714 & 1.401 \\
\hline $\begin{array}{l}\text { Leverage } \\
\text { (DAR) }\end{array}$ & 1.080 & .449 & .222 & 2.405 & .018 & .963 & 1.039 \\
\hline
\end{tabular}

* Corresponding author's e-mail: maria2312natalia@gmail.com

http://openjournal.unpam.ac.id/index.php/JIA 
Jurnal Ilmiah Akuntansi Universitas Pamulang - Vol. 8, No. 1, Januari 2020 - Lasimpala \& Natalia

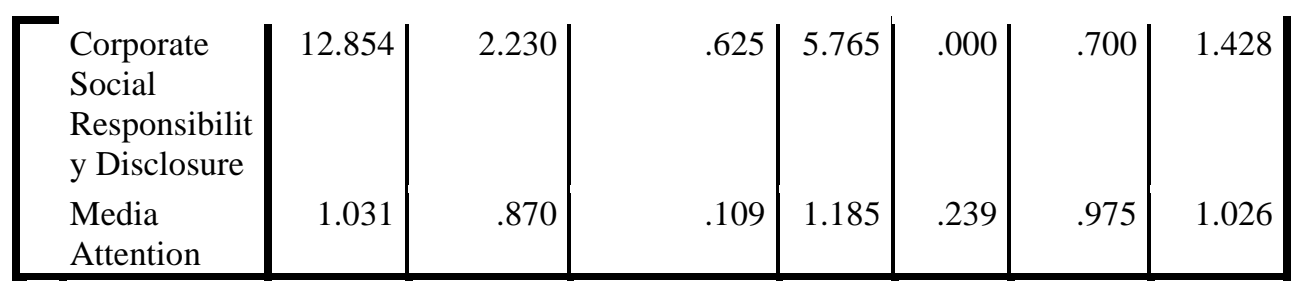

a. Dependent Variable: Nilai Perusahaan (Tobin's Q)

Hasil uji multikolinearitas yang terdapat dalam table 2, menunjukkan bahwa data terbebas dari gejala multikolinieritas karena nilai-nilai yang terdapat dalam VIF berada di bawah nilai VIF maksimal yaitu 10. Selain itu, nilai Tolerance yang lebih besar sama dengan 0,10 pada variabel independen menunjukkan tidak adanya gejala adanya multikolinieritas.

\section{Hasil Uji Heteroskedastisitas}

Tabel 3 Hasil Uji Heteroskedastisitas Coefficientsa

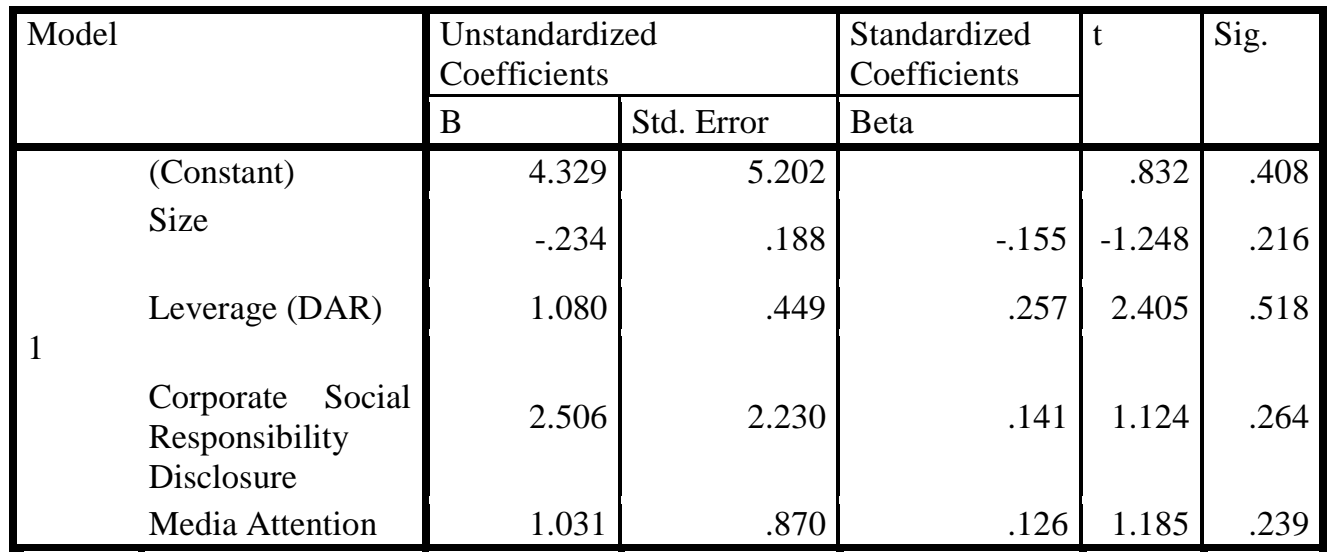

a. Dependent Variable: Unstandardized Residual

Berdasarkan uji Glesjer yang dilakukan, diketahui nilai signifikansi sebesar 0.264 untuk Corporate Social Responsibility Disclosure dan 0.239 untuk media attention. Sementara untuk variabel Size adalah sebesar 0.216 dan Leverage sebesar 0.518, nilai ini lebih besar dari nilai 0.05. Dengan demikian, data yang dimiliki tidak menunjukkan gejala Heteroskedadistitas.

Hasil Uji Hipotesis

Hasil Uji Goodness of Fit

Tabel 4 Uji Koefisien Determinasi Model Summary ${ }^{b}$

\begin{tabular}{|l|l|r|lr|l|l|}
\hline Model & $\mathrm{R}$ & R Square & $\begin{array}{l}\text { Adjusted } \\
\text { Square }\end{array}$ & $\begin{array}{l}\text { Std. Error of the } \\
\text { Estimate }\end{array}$ & Durbin-Watson \\
\hline 1 & $.503^{\mathrm{a}}$ & .253 & & .245 & 2.39066 & 1.920 \\
\hline
\end{tabular}

a. Predictors: (Constant), Corporate Social Responsibility Disclosure

b. Dependent Variable: Nilai Perusahaan (Tobin's Q)

* Corresponding author's e-mail: maria2312natalia@gmail.com

http://openjournal.unpam.ac.id/index.php/JIA 
Jurnal Ilmiah Akuntansi Universitas Pamulang - Vol. 8, No. 1, Januari 2020 - Lasimpala \& Natalia

Berdasarkan pengujian di atas, dipeoleh nilai $\mathrm{R}$ square sebesar 0.253. Dengan demikian, Nilai $\mathrm{R}^{2}$ yang mendekati 1 menunjukkan bahwa variabel bebas memberikan hampir seluruh informasi yang diperlukan dalam meramal variasi variabel independen. Berdasarkan nilai tersebut, sebesar $25.3 \%$ dari Nilai Perusahaan dapat tergambar dari nilai Coporate Social Responsibility.

\section{Pengujian Hipotesis 1 (H1)}

Tabel 5 Hasil Uji Parsial Coefficients $^{\mathrm{a}}$

\begin{tabular}{|c|c|c|c|c|c|}
\hline \multirow[t]{2}{*}{ Model } & \multicolumn{2}{|c|}{$\begin{array}{l}\text { Unstandardized } \\
\text { Coefficients }\end{array}$} & \multirow{2}{*}{$\begin{array}{l}\text { Standardized } \\
\text { Coefficients } \\
\text { Beta }\end{array}$} & \multirow[t]{2}{*}{$\mathrm{T}$} & \multirow[t]{2}{*}{ Sig. } \\
\hline & B & Std. Error & & & \\
\hline (Constant) & -1.724 & .748 & & -2.306 & .024 \\
\hline $\begin{array}{l}\text { Corporate Social } \\
\text { Responsibility } \\
\text { Disclosure }\end{array}$ & 10.348 & 1.927 & .503 & 5.371 & .000 \\
\hline
\end{tabular}

a. Dependent Variable: Nilai Perusahaan (Tobin's Q)

\section{Tabel 6 Hasil Uji F}

ANOVA $^{\mathrm{a}}$

\begin{tabular}{|rl|l|l|l|l|l|}
\hline Model & & \multicolumn{1}{l|}{ Sum of } & df & Mean Square & F & Sig. \\
\hline \multirow{3}{*}{1} & Squares & & & & \\
\hline & Regression & 173.916 & 2 & 86.958 & 15.321 & $.000^{\text {b }}$ \\
& Residual & 476.757 & 84 & 5.676 & & \\
& Total & 650.673 & 86 & & & \\
\hline
\end{tabular}

a. Dependent Variable: Nilai Perusahaan (Tobin's Q)

b. Predictors: (Constant), Media Attention, Corporate Social Responsibility Disclosure

Berdasarkan pengolahan data, didapatkan nilai signifikansi sebesar 0,00 , yang berarti lebih kecil dari 0,05. Artinya Corporate Social Responsibility Disclosure memiliki pengaruh terhadap Nilai Perusahaan (tobin's Q) pada perusahaan manufaktur yang terdaftar di Bursa Efek Indonesia periode 2016.

Pengujian Hipotesis 2 (H2)

Tabel 7 Hasil Uji Parsial Coefficients $^{\mathrm{a}}$

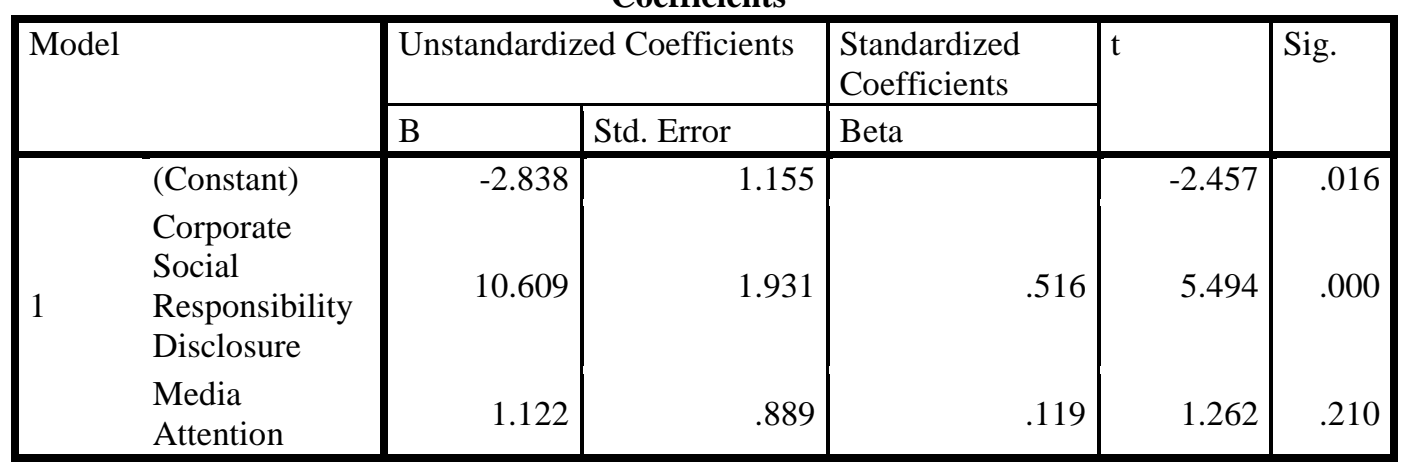

* Corresponding author's e-mail: maria2312natalia@gmail.com http://openjournal.unpam.ac.id/index.php/JIA 
Jurnal Ilmiah Akuntansi Universitas Pamulang - Vol. 8, No. 1, Januari 2020 - Lasimpala \& Natalia

a. Dependent Variable: Nilai Perusahaan (Tobin's Q)

Berdasarkan data di atas, didapatkan nilai pengaruh langsung antara Corporate Social Responsibility Disclosure terhadap Nilai Perusahaan adalah sebesar 0.516. Dengan demikian, besar koefisien pengaruh langsung dari X1 terhadap Y didapat sebesar 0.516. Adapun nilai media attention terhadap Nilai Perusahaan adalah sebesar 0.119. Dengan demikian, besar koefisien dari X2 terhadap Y didapat sebesar 0.119 .

Tabel 8 Analisis Jalur

Correlations

\begin{tabular}{|c|c|c|c|c|}
\hline & & $\begin{array}{l}\text { Corporate Social } \\
\text { Responsibility } \\
\text { Disclosure }\end{array}$ & $\begin{array}{l}\text { Media } \\
\text { Attention }\end{array}$ & $\begin{array}{l}\text { Nilai } \\
\text { Perusahaan } \\
\text { (Tobin's Q) }\end{array}$ \\
\hline \multirow{3}{*}{$\begin{array}{l}\text { Corporate } \quad \text { Social } \\
\text { Responsibility Disclosure }\end{array}$} & $\begin{array}{l}\text { Pearson } \\
\text { Correlation }\end{array}$ & 1 & -.107 & $.503^{* *}$ \\
\hline & Sig. (2-tailed) & & .323 & .000 \\
\hline & $\mathrm{N}$ & 87 & 87 & 87 \\
\hline \multirow{3}{*}{ Media Attention } & $\begin{array}{l}\text { Pearson } \\
\text { Correlation }\end{array}$ & -.107 & 1 & .063 \\
\hline & Sig. (2-tailed) & .323 & & .561 \\
\hline & $\mathrm{N}$ & 87 & 87 & 87 \\
\hline \multirow{4}{*}{$\begin{array}{l}\text { Nilai Perusahaan (Tobin's } \\
\text { Q) }\end{array}$} & Pearson & $.503^{* *}$ & .063 & 1 \\
\hline & Correration & & & \\
\hline & Sig. (2-tailed) & 然 & .561 & \\
\hline & $\mathrm{N}$ & 87 & 87 & 87 \\
\hline
\end{tabular}

**. Correlation is significant at the 0.01 level (2-tailed).

Berdasarkan data di atas, didapatkan nilai hubungan antara Corporate Social Responsibility Disclosure dan media attention memiliki koefisien sebesar 0.107. Dengan demikian, pengaruh yang ada merupakan pengaruh negatif, yaitu sebesar $10.7 \%$.

\section{Pembahasan}

\section{Pengaruh Corporate Social Responsibility terhadap Nilai Perusahaan}

Berdasarkan uji hipotesis yang dilakukan, Corporate Social Responsibility Disclosure memiliki pengaruh terhadap Nilai Perusahaan (tobin's Q) pada perusahaan manufaktur yang terdaftar di Bursa Efek Indonesia periode 2016, dimana pengaruh dari Corporate Social Responsibility Disclosure terhadap Nilai Perusahaan adalah sebesar $25.3 \%$, sedangkan sisanya sebesar $74,7 \%$ dipengaruhi oleh faktor lain diluar Corporate Social Responsibility. Dengan demikian, penelitian ini mengkonfirmasi penelitian yang dilakukan oleh penelitian Li et al (2016) dan Maretno \& Harjoto (2011), yang menunjukkan bahwa Corporate Social Responsibility memiliki dampak positif yang signifikan terhadap Nilai Perusahaan. 
Jurnal Ilmiah Akuntansi Universitas Pamulang - Vol. 8, No. 1, Januari 2020 - Lasimpala \& Natalia

\section{Pengaruh Corporate Social Responsibility terhadap Nilai Perusahaan dengan Media Attention sebagai Variabel Mediasi}

Hasil penelitian menujukkan bahwa media attention tidak mampu memediasi pengaruh pengungkapan Corporate Social Responsibility terhadap Nilai Perusahaan karena pengaruh mediasi yang ada hanya sebesar $0.6 \%$. Nilai ini jauh lebih kecil dari pengaruh langsung, sehingga dianggap tidak terdapat pengaruh mediasi dari media attention. Hasil penelitian ini bertentangan dengan penelitian yang dilakukan oleh $\mathrm{Li}$ et al (2016) yang menyatakan bahwa melalui pengawasan dari pihak eksternal atau para pemangku kepentingan, perusahaan lebih cenderung berkomitmen untuk meningkatkan kinerja Corporate Social Responsibilitysehingga berdampak pada Nilai Perusahaan.

\section{KESIMPULAN}

Penelitian ini bertujuan untuk mengetahui apakah terdapat pengaruh Corporate Social Responsibility Disclosure terhadap Nilai Perusahaan dengan media attention sebagai variabel mediasi terhadap perusahaan manufaktur yang terdaftar (listing) di Bursa Efek Indonesia periode 2016. Langkah yang digunakan adalah dengan mengumpulkan data berupa Annual Report perusahaan manufaktur yang terdaftar di Bursa Efek Indonesia periode 2016 dan informasi perusahaan yang mengungkapkan kegiatan Corporate Social Responsibility dalam website masing-masing perusahaan.

Hasil penelitian menunjukkan bahwa terdapat pengaruh langsung Corporate Social Responsibility Disclosure terhadap Nilai Perusahaan sebesar 25,3\%. Hasil penelitian untuk mengetahui pengaruh Corporate Social Responsibility Disclosure terhadap Nilai Perusahaan dengan media attentionsebagai variabel mediasi, menunjukkan bahwa pengaruh langsungCorporate Social Responsibility Disclosure terhadap Nilai Perusahaan adalah sebesar 0,516. Media attention sebagai mediasi juga memiliki nilai terhadap Nilai Perusahaan sebesar 0,119. Sedangkan, nilai hubungan antara Corporate Social Responsibility Disclosure dan media attention memiliki koefisien sebesar -0.107 sehingga pengaruh yang dimiliki adalah pengaruh negatif. Setelah dilakukan analisis jalur terhadap ketiga variabel tersebut, pengaruh mediasi yang ada hanya sebesar 0,00657 atau 0,6\% jauh lebih kecil dari pengaruh langsung antara Corporate Social Responsibility Disclosure terhadap Nilai Perusahaan, sehingga dianggap media attention tidak mampu memediasi kedua variabel tersebut.

\section{DAFTAR PUSTAKA}

Alfianika, Ninit. (2016). Metode Penelitian Pengarajaran Bahasa Indonesia. Yogyakarta : Deepublish. 
Jurnal Ilmiah Akuntansi Universitas Pamulang - Vol. 8, No. 1, Januari 2020 - Lasimpala \& Natalia

Amaladoss, M.X., Manohar, H.L. (2013). Communicating corporate social responsibility-a case of CSR communication in emerging economies. Corp. Soc. Responsib. Environ. Manag.20(2), 65-80 (2013).

Ananda, Candra Fajri. (2017 : 147). Manajemen Riset dengan Pendekatan Komputasi Statistika. Malang :UB Press.

Budihardjo, Andreas et al. (2011). Pijar-pijar Manajemen Bisnis Indonesia. Jakarta : Prasetiya Mulya.

Branco, Manuel Castelo and Rodrigues Lucia Lima. 2008. Factors Influencing Social Responsibility Disclosure by Portuguese Companies. Journal of Business Ethies, 83.

CNN.(2018). Anies Sebut Limbah di BKT Marunda karena Deterjen Warga. Diperoleh dari https://www.cnnindonesia.com/nasional/2018032414514920-285626/anies-sebut-limbah-di-bkt-marunda-karena-deterjen-warga.

Diakses tanggal 12 September 2018.

Craven, B.M., Marston, C.L. (1997). Investor relations and corporate governance in large UK companies. Corp. Gov. 5(3).

Dewi, Ayu Sri Mahatma \& Wirajaya, Ary.(2013). Pengaruh Struktur Modal, Profitabiolitas dan Ukuran Perusahaan pada Nilai Perusahaan.E-Journal Akuntansi. Vol. 4, No. 2.

Grafstro"m, M., Windell, K. (2011). The role of infomediaries: CSR in the business press during 2000-2009. J. Bus. Ethics 103(2).

Kartini, Dwi. (2009). Corporate social responsibility: Transformasi konsep sustainability management dan implementasi di Indonesia. Bandung : PT. Refika Aditama.

Li et al. (2016). Corporate Social Responsibility, Media Attention and Firm Value: Empirical Research on Chinese Manufacturing firms.

Mardiyanto, Handono. (2009). Inti Sari Manajemen Keuangan. Jakarta : Grasindo.

Maretno, Hoje Jo \& Harjoto, A. (2011). Corporate Governance and Firm Value: The Impact of Corporate Social Responsibility. Journal of Business Ethics. Volume 103, No. 3.

Margaretha, Farah. (2005). Teori dan Aplikasi Manajemen Keuangan: Investasi dan Sumber Dana Jangka Pendek. Jakarta : PT. Grasindo.

Marnelly, T. Romy. (2012). Corporate Social Responsibility (CSR): Tinjauan Teori dan Praktek di Indonesia. Jurnal Aplikasi Bisnis. Vol, 2 No. 2.

Permana, Virgiawan Aditya. (2012). Pengaruh Kinerja Lingkungan dan Karakteristik Perusahaan terhadap Corporate Social Responsibility (CSR) Disclosure (Studi Empiris pada Perusahaan Manufaktur yang Terdaftar di BEI). Diponegoro Journal of Accpunting. Vol. 1, No. 1.

Putra, A., Kristiani, F., \& Yudowati, S. (2017). Pengaruh Corporate Social Responsibility terhadap Nilai Perusahaan dengan Profitabilitas Sebagai

* Corresponding author's e-mail: maria2312natalia@gmail.com

http://openjournal.unpam.ac.id/index.php/JIA 
Jurnal Ilmiah Akuntansi Universitas Pamulang - Vol. 8, No. 1, Januari 2020 - Lasimpala \& Natalia

Variabel Moderating (Studi Empiris pada Sektor Pertambangan yang Terdaftar di Bursa Efek Indonesia Periode 2012-2015).e-Proceeding of Management : Vol.4, No.3 Desember 2017.

Rosiana, Gusti A. M., Juliarsa, Gede.,\& Maria, M. Ratna. (2013). Pengaruh Pengungkapan CSR Terhadap Nilai Perusahaan dengan Profitabiitas Sebagai Variabel Pemoderasi.

Said, Ahmad Lamo.(2015). Corporate Social Responsibility dalam Perspektif Bisnis. Sleman : Grup Penerbitan CV Budi Utama.

Sari, D.V \& Haryanto, A.M. (2013). Pengaruh Profitabilitas, Pertumbuhan Aset, Ukuran Perusahaan, Struktur Aktiva dan Likuiditas terhadap Struktur Modal pada Perusahaan Manufaktur di Bursa Efek Indonesia Tahun 2008-2010. Diponegoro University. Volume 2, Nomor 3, Tahun 2013.

Sattar.(2017). Pengantar Bisnis. Jogjakarta : Deepublish.

Sudana, I Made. (2009). Manajemen Keuangan : Teori dan Praktek. Jakarta : Erlangga.

Sugiyono. (2014). Metode Penelitian Pendidikan Pendekatan Kuantitatif, Kualitatif, dan R\&D. Bandung : Alfabeta. 